\title{
5. Scandalising media freedom: Resurrection of an ancient contempt
}

\section{ABSTHACII}

The ancient charge of 'scandalising the court' (publications aiming at lowering the authority of the court) has had a resurgence in Australia over the past decade, at the very time judges and magistrates have developed an inclination to sue for defamation. The combined effect is to send a warning to media organisations to take care when criticising judicial officers or the judicial process, particularly if that involves implying some improper motive on the part of a judge or magistrate. In New Zealand there have been some isolated but significant threats and cases, particularly in the volatile area of family law. This article reviews some recent Australian and New Zealand cases where a charge of scandalising the court has been either threatened or enforced and considers the implications for freedom of media expression in a new era of anti-terrorism when important questions are being asked about the fairness of justice processes.

Keywords: contempt of court; justice system; media freedom

\section{MARK PEARSON}

Bond University, Queensland

7 HE FORM of contempt of court known as 'scandalising the court'defined as 'any act done or writing published calculated to bring

the court or a judge of the court into contempt or to lower his authority' ( $R$ v. Gray, 1900) - has long been used by small African and Pacific Island states as a mechanism for silencing media criticism of the judicial process. (See, for example, Attorney-General v. Namoa, 2000; and Chaudhary $v$ Attorney-General, 1999; where it was used recently in Tonga and Fiji). In Canada the offence has been found incompatible with that 
country's Charter of Rights and Freedoms, in the United Kingdom it has not been prosecuted successfully against the media since 1931 and in the United States it does not exist at all (Weisenhaus, 2007, pp. 74-75). Sadly, it has been revitalised in Australia over the past decade at the very timemembers of the judiciary have begun to sue for defamation, presenting a dual affront to media freedom. Ithas also been used in a notable case in New Zealand and threatened in another. This is despite the fact that the legislature in New Zealand and the High Court in Australia have made moves to enshrine freedom of communication, in New Zealand with a Bill of Rights and in Australia within a series of decisions through the 1990s guaranteeing free speech on governmental and political matters. This article considers briefly the background to scandalising contempt before reviewing the key cases in the field and considering the resulting implications for judicial critique in the media.

\section{Background to scandalising the court}

One of the most famous examples of scandalising the court was the attack in the Birmingham Daily Argus upon Crown Court Justice Darling at the turn of the last century. Editor Howard Alexander Gray was convicted of contempt forhistirade against the goodjustice, describing him as an 'impudent little man in horse-hair, a microcosm of conceit and empty-headedness' (R. v. Gray, 1900).

The term 'scandalising' was described in the Australian High Court in 1935 as applying to:

publications which tend to detract from the authority and influence of judicial determinations, publications calculated to impair the confidence of the people in the Court's judgments because the matter published aims at lowering the authority of the Court as a whole or that of its judges and excites misgivings as to the integrity, propriety and impartiality brought to the exercise of the judicial office. (R. $v$. Dunbabin; Ex parte Williams, 1935, p. 442)

This type of contempt can be committed by publishing material scandalising the courts or judges by abusing them in scurrilous terms, alleging they are corrupt or lack integrity, or that they have bowed to outside influences in reaching their decisions (Pearson, 2007, p. 109). Historically, the courts have been tolerant of reasonable criticism. Lord Atkin summed up the 
approach with this quote in 1936: 'Justice is not a cloistered virtue; she must be allowed to suffer the scrutiny and respectful, though outspoken, comments of ordinary men' (Ambard v Attorney-General of Trinidad and Tobago, p. 335). This statement reinforced the fact that in Britain the offence was considered to have become obsolete in 1899, as Butler and Rodrick note (2004, p. 282). But, they continue:

This declaration turned out to be premature. The offence remains extant in England, although it has been described as quiescent, as there have been no convictions for scandalising contempt for almost 70 years. In Australia there is no doubt that the offence continues to exist. In fact, prosecutions are relatively common.

As this article sets out to establish, scandalising charges have become even more common in recent years, a disturbing development for media freedom.

The two best-known cases in this area in Australia in the late 20th century were called the 'BLF cases', as both involved officials of a militant union, the Builders' Labourers Federation-Jack Mundey and Norm Gallaghera decade apart. In each case, the accused had made comments (picked up by the media) implying that judges had bowed to union pressure in reaching their decisions. The first, Attorney-General (NSW) v Mundey (1972), occurred during the heat of the anti-apartheid protests against South Africa in the early 1970s. Members of the Builders' Labourers Federation had sawn off the goalposts at the Sydney Cricket Ground in the prelude to a rugby Test match between Australia and South Africa's Springboks. After their trials, a union official, Jack Mundey, told the media the judge should have allowed evidence of broader political material in their defence, such as United Nations documentation on South Africa's race policies. Mundey claimed there had been a miscarriage of justice and that the judge was a racist. Mundey was charged with contempt for these comments, but the charges were dismissed in the Supreme Court because Mundey's comments about the judge being a racist needed to be considered in the broader context of his comments about racism throughout Australian society. The court ruled that Mundey would have been in contempt if he had implied that the judge had been motivated by some racist bias against the accused in reaching his decision. 
The second BLF case, Gallagher v. Durack (1983), a decade later, had a different result. There, Builders' Labourers Federation federal secretary Norm Gallagher won a Federal Court appeal against one contempt charge, but his comments about the judicial process landed him in contempt on a new charge of scandalising the court. Gallagher told the media that industrial action by his union members had exerted enough pressure to force the court to reverse the decision to jail him over the first contempt charge. He told one television channel: 'The rank and file of the union ... has shown such fine support of the officials of the union and I believe that by their actions in demonstrating in walking off jobs ... I believe that has been the main reason for the court changing its mind' (Gallagher v Durack, 1983, p. 239). The Federal Court held that the statement was contemptuous and sentenced Gallagher to three months' jail. (The court justified the jail sentence on the basis that Gallagher had boasted that if he had been fined the union would pay it for him.) The decision was appealed to the High Court, which upheld the contempt conviction. The court said the whole area of scandalising involved balancing the principle of free speech against the need to maintain public confidence in the judicial system. Gallagher's insinuation that the Federal Court had bowed to outside pressure in reaching its decision was calculated to undermine public confidence in the Federal Court. Justice Murphy dissented, saying the case raised important principles of both free speech and justice.

In a more recent case, the Anissa Pty Ltd $v$ Simon Harry Parsons on application of the Prothonotary of the Supreme Court of Victoria, (1999, at para. 19), Justice Cummins of the Supreme Court of Victoria summed up the three basic principles of contempt by scandalising the court:

First, proceeding for contempt of court is not and must not be in diminution of free speech. Second, proceeding for contempt of court is to preserve the administration of justice. Third, proceeding for contempt of court is not to protect the individual person of the judge.

A turning point in the law of scandalising was reached with one of the Australian High Court's famous free speech decisions in 1992Nationwide News Pty Ltd v Wills. There, a newspaper group challenged the federal government's power to legislate against criticism of the Industrial Relations Commission or its members. The High Court held there was an implied constitutional right to criticise importantpublic institutions and that this 
legislation infringed that right. However, the court also ruled that the crime of scandalising the court was not obsolete and that two defences applied to it: truth and fair comment (Chesterman 2000, p. 68). (In other words, it would be a defence to a charge of scandalising the court if you could prove that the substance of your criticisms was true or that your criticisms were made in good faith, were honestly held, fairly conducted and did not imply improper motives on the part of the judiciary.)

In Nationwide News Pty Ltd $v$ Wills, Mason CJ described scandalising as a 'well recognised form of criminal contempt' (at para 21) but suggested there was no contempt at common law 'if all that the defendant does is to exercise his or her ordinary right to criticise, in good faith, the conduct of the court or the judge' (at para 21). He stated the judiciary should be open to criticism and cited US Supreme Court Justice Hugo Black stating in Bridges $v$ California in 1941:

The assumption that respect for the judiciary can be won by shielding judges from published criticism wrongly appraises the character of American public opinion. ... an enforced silence, however limited, solely in the name of preserving the dignity of the bench, would probably engender resentment, suspicion, and contempt much more than it would enhance respect. (pp. 270-271)

Burrows and Cheer (2005, pp. 384-387) offer six danger zones for scandalising the court:

- Extravagant and scurrilous language;

- Vendettas against judges;

- Criticism based on inaccuracies;

- Accusations of bias or impartiality on the part of the judiciary;

- Suggestions judges are susceptible to pressure; and

- The social conditions of the times.

The key recent New Zealand case of scandalising the court, SolicitorGeneral for NZ v. Smith (2004), also raised issues of free expression in relation to that country's Bill of Rights Act. The case was explained well by Cheer (2004). The High Court found MP Nick Smith had made several inflammatory media statements about a custody dispute before the 
Family Court which undermined public confidence in the court and had the potential to interfere with the administration of justice by placing public pressure upon the court. As Burrows and Cheer (2005, p. 386) noted, 'whichever way the Family Court judge decided the case, the public perception would be affected by seeing the pressure that had been so publicly applied' It also convicted TV3 and Radio NZ of the same charge and found the freedom expression provisions of section 14 of the Bill of Rights did not offer protection against a charge of scandalising the court. Justices Wild and MacKenzie stated:

\begin{abstract}
We do not accept that the offence of scandalising the Court cannot be justified as a reasonable limitation upon freedom of expression... The rights guaranteed by the BORA [Bill of Rights Act] depend upon the rule of law, the upholding of which is the function of the Courts. Courts can only effectively discharge that function if they command the authority and respect of the public. A limit upon conduct which undermines that authority and respect is thus not only commensurate with the rights and freedoms contained in the BORA, but is ultimately necessary to ensure that they are upheld. (Solicitor-General for NZv Smith, 2004, p. 568, cited in Burrows and Cheer, 2005, p. 384)
\end{abstract}

Thus, in both countries, despite the legislature and the highest courts enshrining free expression about politics and government, the courts have decided this ancient punishment should still be available to the judiciary.

\title{
The resurgence of scandalising the court
}

Over the past 10 years in Australia and New Zealand there have been several charges or threats of scandalising the court involving the media in a variety of ways, all containing extreme statements about the judiciary. These include:

\section{Re South Australian Telecasters Limited (1998).}

The Family Court of Australia stopped Channel Seven in Adelaide from broadcasting a current affairs story about a custody battle between the natural parents of two children and their foster mother. As well as identification issues related to the dispute taking place in a small semi-rural town, and the risk of sub judice contempt related to the upcoming custody hearing, Chief Justice Nicholson expressed concern about the 
potential for scandalising the court. He said the report risked bringing the court into contempt and lowering its authority.

Alice in Wonderland case (2001).

As Burrows and Cheer (2005, p. 387) report, an Environment Court judge asked counsel for argument over whether a contempt by scandalising had been committed when a local body politician criticised an Environment Court decision as 'Alice in Wonderland' in an issued statement. He also called upon landowners to state their disapproval to the judge. The matter was eventually resolved with an apology where the politician withdrew the comments.

Hoser \& Kotabi Pty Ltd v The Queen (2003).

The author of two books about police corruption in Victoria was fined $\mathrm{A} \$ 3000$ and his publishing company fined $\mathrm{A} \$ 2000$ for making malicious and baseless allegations of bias and impropriety against two County Court judges who had tried earlier cases involving the author. A defence that the statements were fair comment made in good faith failed.

Bell v Umina Beach Bowling Club Ltd (No 2) (2003).

Directors of a New South Wales bowls club were disgruntled that their suspension of a fellow director had been ruled void by the NSW Chief Judge in Equity Justice Young. The Central Coast Herald wrote a report of the decision, ending with the sentence: 'Two of the club directors indicated an appeal against Justice Young who they accused of bias.' The judge warned the comment was a contempt by scandalising, but handled it with a warning. Justice Young said: 'Of course there is a wide range of legitimate criticism that can be made of courts and their decisions. However a statement to a newspaper of wide circulation that the only reason the spokesman lost was because the judge was biased goes beyond legitimate criticism, weakens the authority of the court in the eyes of the public and is a contempt.'

Website case (2003).

A New Zealand-based web site listed 14 judges it was purportedly investigating for 'corruption, incompetence and suspect character' and threatened to release further information proving these allegations. Burrows and Cheer $(2005$, p. 385$)$ report that the publication prompted a letter from the Solicitor-General and the material was subsequently removed from the site. Attorney-General for State of Queensland v Colin Lovitt QC (2003). Barrister Colin Lovitt was so frustrated with a Queensland magistrate's 
ruling in a high-profile case, he turned to journalists covering the hearing and declared: 'This bloke's a complete cretin. Surely they can't all be like this.' The comments were reported and journalists testified they had heard him. Queensland Supreme Court Justice Richard Chesterman fined him A $\$ 10,000$, saying the statement constituted both 'scurrilous abuse and an attack upon the authority of the court'.

Mills \& Ors v Townsville City Council \& Anor (No. 2) (2003).

Planning and Environment Court Judge Clive Wall considered charging three Townsville councillors with contempt by scandalising when they were quoted criticising his decision to reject their approval of a nursing home development. One accused him of making decisions on design and aesthetics and another suggested the judge had 'usurped the role of council'. Mayor Tony Mooney was quoted as saying: 'Those appointed to the bench are not appointed by divine intervention [and] they don't always get it right.' Judge Wall decided the comments did not amount to contempt by scandalising because they could not be said to be of a character calculated to interfere with the administration of justice or to undermine the public confidence in the proper functioning of the courts'. 'Courts should not rush to be overly critical of criticism, even discourteous, wrong and mistaken criticism, as the present is', he said.

Solicitor-General v Smith (2004).

MP Nick Smith was fined NZ\$5000, TV3NZ \$25,000 and Radio New Zealand NZ\$5000 by the New Zealand High Court over comments he made about a Family Court custody case which were broadcast on the television and radio stations. The comments were inaccurate, applied pressure on the court, undermined confidence in the judicial process and had the potential to interfere with the administration of justice, the court held.

DPP v Francis \& Anor (No. 2) (2006).

Veteran Adelaide broadcaster Bob Francis was given a nine week suspended jail sentence and fined A \$20,000 over a 2005 programme in which he criticised a magistrate for considering granting bail to a man accused of possessing child pornography. (Magistrate Gary Gumpl was obliged under legislation to hear a bail application.) Francis told his audience: 'Oh, smash the judge's face in.' The magistrate also settled out of court for a reported A $\$ 110,000$ defamation payout (McGarry 2006). 


\section{Environment Protection Authority v Pannowitz (2006).}

Steepleton Pty Ltd and its director Kenneth Pannowitz were convicted and fined by the Environment Protection Authority in New South Wales for unlawful transport and disposal of waste. Part of their sentence was an order to place an advertisement in the Newcastle Herald newspaper with stipulated wording announcing their conviction. The director changed the notice in various ways and added the sentence 'This matter has been referred by Steepleton to ICAC for further investigation'. Land and Environment Court Justice Lloyd found the suggestion that a corruption body was being called upon to investigate the court had 'an inherent tendency to scandalise the court'. He also ruled Pannowitz had interfered with the course of justice by changing the size, position and wording of the notice.

\section{Family Court criticism}

Family law cases can be particularly volatile and the Family Court in both countries has been subject to harsh criticism by both litigants and the media, some of which have led to scandalising contempt charges as noted above in Re South Australian Telecasters Limited (1998) and SolicitorGeneral v Smith (2004). Other scandalising charges have been pursued against Family Court litigants without involving the media. Disaffected fathers who have lost custody of their children have often been scathing in their criticism of the court. As Lane (2000, p. 14) reported, the Family Court brought scandalising charges against four of its strident critics who protested with placards and leaflets outside its building in Melbourne in 1998, but the cases fell over when a judge threw out the case against the first, 'PT'. In New Zealand, such individuals have faced other charges. For example, Rowan (2007) reports that the founder of the Hands On Equal Parent Trust, Jim Baily, was charged with disorderly conduct over his protest against the Family Court by driving a van with a loudspeaker around the streets of Tauranga. The charges were withdrawn.

Heads of the Family Court in both countries took public stances in 2006 to address such critics. New Zealand's Principal Family Court Judge Peter Boshier said the media's reportage of men's groups' gripes about the court's alleged secrecy, biases and unfair processes was itself often biased and undertaken without reporters actually attending the court proceedings. 'The reporting of the father's groups' protests shows that the more strident and extreme the 
claims made the more likely the media will give them publicity - and uncritical publicity,' he said (Boshier, 2006, p. 5). In Australia, the Chief Justice of the Family Court, Diana Bryant, went public to counter criticism that her court was biased by announcing the court would be collecting statistics including those showing the percentage of arrangements involving or excluding fathers (Porter, 2006, p. 6).

\section{When magistrates and judges sue}

Complicating the scandalising cases is the fact that members of the judiciary have become more inclined to sue for defamation in recent years, as evidenced by the award of A $\$ 246,500$ in damages in 2002 to Victorian Deputy Magistrate Jelena Popovic over a Herald Sun article by Andrew Bolt (Popovic v Herald \& Weekly Times Ltd and Anor, 2002), and the 2005 victory over the Sydney Morning Herald by NSW magistrate Pat O'Shane (John Fairfax Publications Pty Ltd v O'Shane, 2005). Burrows and Cheer (2005, p. 383 footnote 29) also record a New Zealand newspaper report of a judge settling a defamation action against a media organisation. The propensity of the judiciary to sue means media organisations potentially face both criminal and civil responses to their harsh critique of the administration of justice in the form of a scandalising contempt charge and a defamation suit.

\section{Conclusion and directions}

All this is not to say that judges in either country jump at the opportunity to charge media organisations with contempt by scandalising. Media outlets do indeed publish quite harsh criticisms of the judiciary and get away with it. For example, the editor of Sydney's Daily Telegraph, David Penberthy, almost challenged the courts to charge him with contempt when he reported that District Court Judge Ian Dodd had developed quite a reputation for going to sleep while presiding over cases. Penberthy started his piece as follows:

This might constitute a contempt of court. But we thought we'd run it anyway, as there's every chance the judge in question will be curled up under his judicial sombrero, oblivious to any slur against his name. (Penberthy, 2005, p. 21) 
While Penberthy went ahead and published his humorous exposé of the sleeping judge, the point for this article is more that he was 'chilled' enough by the contempt laws to verbalise the risk in his very first sentence. An ancient law hangs like a guillotine over fair and open reportage in the modern era.

More than 20 years ago the Australian Law Reform Commission (1987) criticised the law of scandalising on two main grounds and recommended its common law version be abolished. The first criticism was that there was no need to prove the accused intended to impair public confidence in the administration of justice; it was enough that the accused published the remarks intentionally (para 414). Secondly, there was no formal defence of justification available to the accused; the truth or falsity of the published remarks was irrelevant (para 415). Of course, as noted above, the High Court indeed decided truth would be a defence to scandalising in Nationwide News Pty Ltd $v$ Wills (1992).

While the commission recommended scandalising be abolished from the common law, it suggested it be replaced by a limited offence which prohibited the publication of an allegation imputing misconduct to a judge if it was likely to cause serious harm to the judge's reputation in his or her official capacity (para 460). Liability would lie with each officer of the media organisation in a position to exercise control over the publication (para 261) and the initial maker of the scandalising statement if he or she knew, or should have known, the allegation would be published (para 264). The commission also recommended the defence of justification (if the accused proved the allegation was true or believed it was true on reasonable grounds) and the defence of it being made as part of a fair and accurate report of court or parliament (para 460). The offence would be tried by jury except when all concerned had consented to have it tried summarily by a magistrate (para 476,479 ).

The commission's recommendations, the free speech cases in the Australian High Court in the early 1990s, the higher public profile of the judiciary and the fact that more judicial officers were pursuing defamation actions to defend their reputations all raised hopes that the authorities would not pursue charges of scandalising the court. Such hopes were reinforced in 2005 when Federal Court Justice Ronald Sackville delivered the 13th Lucinda Lecture at Monash University (Sackville, 2005). Sackville asked 'How fragile are the courts?' and traced the history of criticism of the courts, including a critique of scandalising contempt. He supported the ALRC by suggesting 
courts should be able to resort to some powers 'in the rare cases where verbal attacks pose a genuine threat to the standing of the judiciary'. He also suggested that, like politicians and other public officials, judges should be able to sue for defamation where their reputations have been unfairly damaged. He concluded:

But the independence of the judiciary does not justify conferring on judges greater protection than those representatives or officials enjoy. It is to be hoped that the High Court will interpret the scope of the implied freedom of communication more broadly than recent decisions might suggest. If the High Court does not do so, there is a strong case for legislation to bring the principles governing criticism of the Australian judiciary into line with those of other liberal democracies. (Sackville, 2005, p. 24)

Despite Justice Sackville's refreshing perspective reinforcing the recommendations of the ALRC 18 years earlier, it seems that in recent years such charges have had somewhat of a resurgence in Australia and, to a lesser extent, in New Zealand.

Whether or not this has resulted in a debilitating 'chill' upon media critique of the courts is a moot point, but journalists certainly need to ensure that any criticism of the judiciary and the legal system is carefully phrased and measured so that it does not unfairly imply any wrongdoing that might erode public confidence. Journalists should note that, while some of the media organisations mentioned above escaped contempt charges when they reported the contemptuous statements of others (such as disgruntled fathers on the steps of the Family Court) it is open to the authorities to prosecute both the individuals who make contemptuous comments (at a press conference, for example) and the media outlet that reported the comments, as they did in SolicitorGeneral v Smith (2004) in New Zealand. Litaba (2003) noted that while scandalising the court should not be used to protect individual judges against reputational attacks, there were numerous examples where judges seemed to have 'stood on their personal dignity'. Further, Litaba questioned whether under the existing law truth as a defence applied, despite the High Court's statements on the matter in Nationwide News Pty Ltd $v$ Wills (1992), a disturbing insight given that part of the democratic process should surely be the right to make legitimate, well founded, criticism of the judicial process. 
The slim risk of being charged with scandalising the court should not prevent journalists partaking in fair, well-reasoned criticism of the administration of justice. It is only when the criticism is personal, scurrilous abuse of a judge, which brings the judicial system into disrepute, or when it implies some improper motive on the part of the judiciary that it is more likely to overstep the mark. Nevertheless, all in the media would argue that judges and the judicial process should be open to such criticism. This has been even more the case in recent years when judges themselves have spoken about their decisions in public forums. Family Court and High Court justices, particularly, have been vocal on broader policy issues affecting the workings of the justice system. Many welcome such a public profile of the judiciary, but argue that judges cannot adopt such a stance and later hide behind the protections of ancient laws, such as scandalising the court, to punish those who have publicly disagreed with them publicly.

The need for unshackled critique is even more pressing in an era when anti-terrorism laws leave so many court processes open to criticism and when the sentencing of criminals is such a heated political topic.

Media groups, such as Australia's Right to Know lobby, and the press councils in both countries, should press for greater clarity in the law of scandalising. It would have the advantage of allowing reasoned public criticism of judges and the court system and sound investigative reporting of suspicious judicial practices without fear of reprisal from an irate judge wielding summary powers. Media freedom should not be held to ransom by 'impudent little men in horsehair, microcosms of conceit and empty-headedness' nor, for that matter, by 'snoring wigs curled up under their judicial sombreros'.

\section{References}

Australian Law Reform Commission (ALRC). (1987). Report no. 35-contempt, Australian Government Publishing Service, Canberra. [Electronic version.] Boshier, P. (2006, August 9). Fair deal for Family Court. Dominion Post, p. 5.

Burrows, J. and \& Cheer, U. (2005). Media law in New Zealand. (5th ed.). South Melbourne: Oxford University Press.

Butler, D. \& Rodrick, S. (2004). Australian media law. (2nd ed). Sydney: Thomson Law Book Company.

Chesterman, M. (2000) Freedom of speech in Australian law: A delicate plant. Aldershot: Ashgate Dartmouth.

Cheer, U. (2004). New Zealand media law update. Recent developments - defamation, censorship and contempt. Media and Arts Law Review. 9 (3): 237-246. 
Lane, B. (2000, March 8). Street protester beats judges at own game. The Australian. p. 14.

Litaba, O. (2003). Does the 'offence' of contempt by scandalising the court have a valid place in the law of modern day Australia? [Electronic version]. DeakinLRev 6.

McGarry, A. (2006, 3 August) Jail for Bob the broadcaster? The Australian, p. 14.

Pearson, M. (2007). The journalist's guide to media law. Dealing with legal and ethical issues. (3rd ed.). Allen \& Unwin, Sydney.

Porter, L. (2006, December 24). Family Court fights back over bias claims. Sunday Age. p. 6.

Rowan, J. (2007, January 26). Family Court protester avoids conviction. New Zealand Herald.

Sackville, Justice R. (2005). How fragile are the courts? Freedom of speech and criticism of the judiciary. 13th Lucinda Lecture. Monash University, 29 August 2005. Retrieved 10 March 2008, from: www.wbde.org/documents/2005_Aug_29_ Justice_Sackvill_\%20Re_Criticism_of Judiciary.pdf

Weisenhaus, D. (2007). Hong Kong media law. A guide for journalists and media professionals. Hong Kong: HK University Press.

\section{Cases cited}

Ambard v. Attorney-General of Trinidad and Tobago [1936] AC 322.

Anissa Pty Ltd $v$ Simon Harry Parsons on application of the Prothonotary of the Supreme Court of Victoria [1999] VSC 430. Retrieved 10 March 2008, from: www.austlii.edu.au//cgi-bin/disp.pl/au/cases/vic/VSC/1999/430.html.

Attorney-General v Namoa [2000] TOSC 13 Retrieved 10 March 2008, from: www.paclii.org/to/cases/TOSC/2000/13.html.

Attorney-General NSW v. Mundey [1972] 2 NSWLR 887.

Attorney-General for State of Queensland v Colin Lovitt QC [2003] QSC 279.

Retrieved 10 March 2008, from:

www.austlii.edu.au/au/cases/qld/QSC/2003/279.html.

Bell v. Umina Beach Bowling Club Ltd (No 2) [2003] NSWSC 846 Retrieved 10 March

2008, from: www.austlii.edu.au/au/cases/nsw/supreme ct/2003/846.html.

Bridges v. California (1941) 314 US 252.

Chaudhary v Attorney-General [1999] FJCA 23, [17] (Fiji Court of Appeal). Retrieved March 10, 2008 from: www.paclii.org/fj/cases/FJCA/1999/27.html.

DPP v Francis \& Anor (No. 2) [2006] SASC 261 Retrieved 10 March 2008, from:

www.austlii.edu.au/cgi-bin/sinodisp/au/cases/sa/SASC/2006/261.html.

Environment Protection Authority v Pannowitz [2006] NSWLEC 219 Retrieved

10 March 2008, from:

www.austlii.edu.au/au/cases/nsw/NSWLEC/2006/219.html.

Gallagher v. Durack (1983) 152 CLR 238.

Hoser \& Kotabi Pty Ltd $v$ The Queen (ex parte The Attorney-General for the State of Victoria); The Queen (ex parte The Attorney-General for the State of Victoria) v Hoser \& Kotabi Pty Ltd [2003] VSCA 194 Retrieved 10 March 2008, from: www.austlii.edu.au/cgi-bin/disp.pl/au/cases/vic/VSCA/2003/194.html. 
THE FUTURE OF MAINSTREAM MEDIA

John Fairfax Publications Pty Ltd v O'Shane [2005] NSWCA 164.

Retrieved 10 March 2008, from:

www.austlii.edu.au/cgi-bin/sinodisp/au/cases/nsw/NSWCA/2005/164.html.

Mills \& Ors v. Townsville City Council \& Anor (No. 2) [2003] QPEC 18 Retrieved

10 March 2008, from: www.austlii.edu.au/au/cases/qld/QPEC/2003/18.html.

Nationwide News Pty Ltd v. Wills (1992) 177 CLR 1.

Popovic v Herald \& Weekly Times Ltd and Anor [2002] VSC 174

Retrieved 10 March 2008, from:

www.austlii.edu.au/cgibin/sinodisp/au/cases/vic/VICSC/2002/174.html.

Re South Australian Telecasters Limited (Publication Injunction) [1998] FamCA 117 Retrieved 10 March 2008, from:

www.austlii.edu.au/cgibin/disp.pl/au/cases/cth/family_ct/1998/117.html

$R v$ Dunbabin; Ex parte Williams (1935) 53 CLR 419.

$R v$ Gray [1900] 2 QB 36.

Solicitor-General v. Smith [2004] 2 NZLR 540.

Dr Mark Pearson is professor of journalism and director of the Centre for New Media Research and Education at Bond University, Queensland, Australia. He thanks the reviewers of this paper for their useful suggestions and advises that some descriptive passages have been excerpted from his text, The Journalist's Guide to Media Law (3rd ed), Allen \& Unwin, Sydney, 2007.

mpearson@staff.bond.edu.au 